\title{
Factors affecting nectar sugar composition in chiropterophilic plants
}

\section{Factores que afectan la composición de azúcares en el néctar de plantas quiropterofílicas}

\author{
Nelly Rodríguez-Peña ${ }^{\mathrm{a}, \mathrm{f}, *}$, Kathryn E. Stoner ${ }^{\mathrm{a}, \mathrm{b}}$, Cesar M. Flores-Ortiz ${ }^{\mathrm{c}}$, Jorge Ayala-Berdón ${ }^{\mathrm{a}, \mathrm{g}}$, \\ Miguel A. Munguía-Rosas ${ }^{\mathrm{d}}$, Víctor Sánchez-Cordero ${ }^{\mathrm{e}}$, Jorge E. Schondube ${ }^{\mathrm{a}}$ \\ a Instituto de Investigaciones en Ecosistemas y Sustentabilidad, Universidad Nacional Autónoma de México, Antigua Carretera a Pátzcuaro Núm. 8701, Col. Ex \\ Hacienda de San José de la Huerta, 58190 Morelia, Michoacán, Mexico \\ ${ }^{\mathrm{b}}$ Department of Fish, Wildlife and Conservation Ecology, New Mexico State University, 1780 E University Ave, Las Cruces, NM 88003, USA

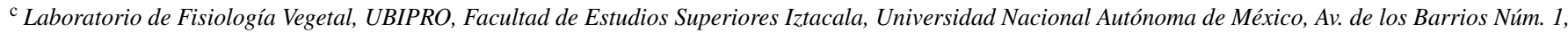 \\ Colonia Los Reyes Iztacala, 54090 Tlalnepantla, Estado de México, Mexico \\ d Laboratorio de Ecología Terrestre, Centro de Investigación y Estudios Avanzados del Instituto Politécnico Nacional, Km. 6 Antigua carretera a Progreso, \\ Apartado postal 73, Cordemex, 97310 Mérida, Yucatán, Mexico \\ e Departamento de Zoología, Instituto de Biología, Universidad Nacional Autónoma de México, Apartado postal 70-153, Del. Coyoacán, 04510 México, D.F., \\ Mexico \\ ${ }^{\mathrm{f}}$ Centro de Tlaxcala de Biología de la Conducta, Universidad Autónoma de Tlaxcala, Carretera Tlaxcala-Puebla Km. 1.5, 90062 Tlaxcala de Xicontencatl, \\ Tlaxcala, Mexico \\ g Conacyt Research Fellow, Universidad Autónoma de Tlaxcala, Carretera Tlaxcala-Puebla Km. 1.5, 90062 Tlaxcala de Xicontencatl, Tlaxcala, Mexico
}

Received 28 February 2015; accepted 16 December 2015

Available online 6 May 2016

\begin{abstract}
Most pollinators prefer the sugars present in the nectar they consume, so it has been hypothesized that they have molded nectar trait evolution. However, nectar-feeding bats do not exhibit preferences for the sugars present in their diet. We analyzed the role that biochemical and ecological factors could play in shaping the nectar traits of chiropterophilic plants. We studied nectar traits and flower production in 49 plant species. We evaluated the relationship between nectar concentration and sugar composition using phylogenetically independent contrasts and if nectar traits were related to flower production using a Manova. We found that 42 species produced high hexoses nectars, and 7 species produced sucrose rich nectars. Phylogenetically independent contrasts showed that nectar concentration was negatively related to glucose content, positively related to fructose content, and was not related to sucrose content. A negative relationship was found from glucose and fructose contents to sucrose content, and glucose content was negatively related to fructose content. Finally, we did not found any relationship between nectar traits and the plants' flowering strategies. We conclude that bat physiology and the relative low evolutionary time of the interaction between plants and bats may determine the lack of pattern in the nectar characteristics of chiropterophilic plants.

All Rights Reserved @ 2016 Universidad Nacional Autónoma de México, Instituto de Biología. This is an open access item distributed under the Creative Commons CC License BY-NC-ND 4.0.
\end{abstract}

Keywords: Chiropterophilic plants; Ecological factors; Nectar biochemistry; Nectar sugar composition

\section{Resumen}

La mayoría de los polinizadores prefieren los azúcares presentes en el néctar que consumen, por lo que se ha especulado que estos han moldeado la evolución de los rasgos del néctar. Sin embargo, los murciélagos nectarívoros no muestran preferencias por los azúcares presentes en su dieta. Analizamos el papel que los factores bioquímicos y ecológicos pueden desempeñar en los rasgos de néctar de 32 plantas quirotperofílicas. Se estudiaron las características del néctar y la producción de flores en 49 especies de plantas. Se evaluó la relación entre la concentración del néctar y la composición de azúcares usando contrastes filogenéticamente independientes y si los rasgos del néctar están relacionados con la producción de flores utilizando una Manova. Se encontró que 42 especies producen néctares con altos contenidos de hexosas y 7 especies producen néctares ricos

\footnotetext{
* Corresponding author.

E-mail address: onrodriguezpena@gmail.com (N. Rodríguez-Peña).

Peer Review under the responsibility of Universidad Nacional Autónoma de México.
} 
en sacarosa. Los contrastes filogenéticamente independientes mostraron que la concentración de néctar se relaciona negativamente con el contenido de glucosa, positivamente con el de fructosa y no tuvo relación con el contenido de sacarosa. Se encontró una relación negativa del contenido de glucosa y fructosa con el de sacarosa y el contenido de glucosa se relacionó negativamente con el de fructosa. Por último, no encontramos ninguna relación entre los rasgos de néctar y las estrategias de floración. Concluimos que la fisiología de los murciélagos y el poco tiempo evolutivo de la interacción entre las plantas y los murciélagos pueden determinar la falta de patrón en los rasgos del néctar quiropterofílico.

Derechos Reservados () 2016 Universidad Nacional Autónoma de México, Instituto de Biología. Este es un artículo de acceso abierto distribuido bajo los términos de la Licencia Creative Commons CC BY-NC-ND 4.0.

Palabras clave: Plantas quiropterofílicas; Factores ecológicos; Bioquímica del néctar; Composición de azúcar del néctar

\section{Introduction}

Nectar constitutes the most important energy source that plants offer to pollinators (Simpson \& Neff, 1983). The 3 most common and abundant sugars in nectar are by far the hexose monosaccharides glucose and fructose, and the disaccharide sucrose (Baker \& Baker, 1983). The sugar composition and other characteristics of nectar vary with biochemical, ecological and evolutionary factors (Baker, Baker, \& Hodges, 1998; Nicolson, 1998; Ornelas, Ordano, De-Nova, Quintero, \& Garland, 2007).

Biochemically, sugar composition of nectar may vary due to changes in the activity of nectary enzymes and to osmoregulation processes caused by the osmotic pressure generated by the different sugars (Nicolson, 1998; Nicolson \& Flemin, 2003). Nectar sugars are derived from sucrose translocated in phloem sap. Sucrose is either secreted into nectar, or it is hydrolyzed in the nectary walls by the activity of invertase enzymes into glucose and fructose (De la Barrera \& Nobel, 2004; Nicolson, 2002). As a result, the final sugar composition of nectar is determined by both the activity and amount of invertase enzyme in the nectary (Sturm \& Guo-Qing, 1999; Woodson \& Wang, 1987). Sucrose hydrolysis into hexoses may increase nectar osmolality, causing water to move from the nectary walls into nectar and thus resulting in more dilute nectars (Nicolson, 1998, 2002). As consequence, nectar sugar composition could affect other nectar traits such as volume and concentration. For example, a dichotomy among volume and concentration with sugar composition has been observed in bird-pollinated flowers in which dilute and copious nectar is generally hexose-rich, while concentrated and less copious nectar is usually sucrose-rich (Baker \& Baker, 1983; Lotz \& Schondube, 2006; Martínez-del Río, Baker, \& Baker, 1992; Nicolson, 1998; Nicolson \& Flemin, 2003). Nevertheless, this pattern has not been evaluated for chiropterophilic plants.

The variation in sugar composition, nectar volume and nectar sugar concentration also are affected at ecological and evolutionary levels by plant mechanisms that are selected based on nectar production costs and by their pollinators' physiology. Several authors have stated that nectar production is costly for plants in terms of the amount of energy invested (Ashman \& Shoen, 1997; Pleasants \& Chaplin, 1983; Southwick, 1984). However, it has also been suggested that nectar production could have small energetic costs (Golubov, Mandujano, Montaña, López-Portillo, \& Eguiarte, 2004; Pyke, 1992). Differences in nectar volume on the basis of a cost-benefit balance, has been also explained in which plants are "fitter" when they produce the smallest possible nectar volume to attract their pollinators (Lanza, Smith, Sack, \& Cash, 1995).

Additionally, preferences of nectar-feeding foragers, based both on their morphology and physiology, also could have selective effects on the evolution of nectar characteristics (Baker \& Baker, 1983; Baker et al., 1998; Erhardt, 1991; Faegri \& van der Pijl, 1979; Heinrich \& Raven, 1972; Martínez-del Río, Stevens, Daneke, \& Andreadis, 1988; Martínez-del Río et al., 1992; Martínez-del Río, Schondube, \& McWhorter, 2001; Ornelas et al., 2007). However, in the case of Neotropical nectarivorous bats, no evidence has been found of bats preferring the dominant sugars (glucose and fructose) present in the nectar they commonly ingest in nature (Herrera, 1999; Rodríguez-Peña et al., 2007). These findings cast a shadow of doubt on the validity of the hypothesis that bats' preferences could act as a selective pressure on the nectar composition of the plants they visit. The prevalence of hexose-dominated nectars among bat-pollinated plants in the Neotropics is an ecological pattern that remains to be explained.

The goal of our study was to analyze nectar traits (i.e. nectar sugar composition and concentration) of chiropterophilic plants, and use this information to understand how these traits could be influenced by biochemical and ecological factors. We analyzed data on the nectar traits of 49 Neotropical plant species that present chiropterophilic flowers. We used the data to evaluate: (1) the relationship between nectar traits (nectar concentration and sugar composition), and (2) the relationship between nectar traits and flowering strategies. First, we hypothesized that because chiropterophilic plant species produce dilute nectars with a greater proportion of hexoses than sucrose (Baker et al., 1998), the nectar concentration will be positively related with sucrose and negatively related with glucose and fructose (Nicolson, 1998). Second, because the hydrolysis of sucrose produces 1 molecule of glucose and 1 molecule of fructose (Nicolson, 2002), chiropterophilic nectars will show equal amounts of glucose and fructose, and the content of hexoses will show a negative relationship with the content of sucrose. Third, because flowering strategies and nectar traits are related to reproductive costs (Southwick, 1984), we predicted that plant species with high flower production should produce dilute nectar with low sucrose proportions, whereas plant species with low flower production will produce more concentrated nectar with greater sucrose proportions. 
Table 1

Nectar traits of 12 chiropterophilic plant species in the Tropical Dry Forest at the Chamela-Cuixmala Biosphere Reserve. Nectar volume was measured $1 \mathrm{~h}$ after anthesis with glass capillary tubes $(\mu 1)$; (mean $\pm \mathrm{SD}$ ) (range) (number of flowers). Concentration: mean $\pm \mathrm{SD}$ (values range) (number of flowers). Energy contained in nectar was obtained by multiplying the total concentration values by each sugar type values and then, multiplied by their molar enthalpy value (2,813.1 and 5,647; for hexoses and sucrose, respectively; Domalsky, 1972). Energy values where referred to are $100 \mathrm{ml}$ of nectar (kJ), and/or to mean energy per flower (in relation to the original volume found in each flower in $\mathrm{kJ})$. Sugar ratios and nectar type: sucrose-dominant $(\mathrm{SD})=$ sucrose/(glucose + fructose) ratio is greater than 0.999 ; sucrose-rich $(\mathrm{SR})=$ ratios between 0.5 and 0.999 ; hexose-rich $(\mathrm{HR})=$ ratios between 0.1 and 0.499 ; and hexose-dominant $(\mathrm{HD})=$ ratios less than 0.1$)$.

\begin{tabular}{|c|c|c|c|c|c|c|c|c|c|}
\hline Family and species & $\begin{array}{l}\text { Nectar volume }(\mu \mathrm{l}) \\
\text { Mean } \pm \text { SD }\end{array}$ & $\begin{array}{l}\text { Nectar } \\
\text { concentration } \\
\left({ }^{\circ} \text { Brix }\right) \\
\text { Mean } \pm \mathrm{SD}\end{array}$ & $\begin{array}{l}\text { Fructose }(\%) \\
\text { Mean } \pm \text { SD }\end{array}$ & $\begin{array}{l}\text { Glucose }(\%) \\
\text { Mean } \pm \text { SD }\end{array}$ & $\begin{array}{l}\text { Sucrose }(\%) \\
\text { Mean } \pm \text { SD }\end{array}$ & $\begin{array}{l}\text { Energy contained in } \\
100 \mathrm{ml} \text { of nectar } \\
(\mathrm{kJ}) \\
\text { Mean } \pm \mathrm{SD}\end{array}$ & $\begin{array}{l}\text { Energy/flower }(\mathrm{kJ}) \\
\text { Mean } \pm \mathrm{SD}\end{array}$ & Sugar ratio $(n)$ & $\begin{array}{l}\text { Flowering } \\
\text { duration/no. of } \\
\text { flowers (months } / n \text { ) }\end{array}$ \\
\hline \multicolumn{10}{|l|}{ Bignoniaceae } \\
\hline Crescentia alata & $\begin{array}{l}115.47 \pm 11.38 \\
(15-580 / n=104)\end{array}$ & $\begin{array}{l}20.05 \pm 0.39 \\
(12-27 / n=81)\end{array}$ & $41.03 \pm 0.70$ & $29.25 \pm 1.09$ & $29.72 \pm 1.58$ & $\begin{array}{l}310.55 \pm 56.27 \\
(n=80)\end{array}$ & $\begin{array}{l}4.96 \pm 3.22 \\
(n=80)\end{array}$ & $3 / 743$ & $1 / 50$ \\
\hline \multicolumn{10}{|l|}{ Malvaceae } \\
\hline Ceiba grandiflora & $\begin{array}{l}120.26 \pm 19.51 \\
(24.3-584.2 / n=240)\end{array}$ & $\begin{array}{l}18.03 \pm 0.93 \\
(5-25 / n=28)\end{array}$ & $46.82 \pm 0.86$ & $39.43 \pm 1.60$ & $13.75 \pm 1.91$ & $\begin{array}{l}295.76 \pm 75.69 \\
(n=28)\end{array}$ & $\begin{array}{l}4.12 \pm 2.93 \\
(n=28)\end{array}$ & $4 / 875$ & $9 / 10$ \\
\hline Ceiba pentandra & $\begin{array}{l}127.44 \pm 3.26 \\
(19-300 / n=240)\end{array}$ & $\begin{array}{l}16.66 \pm 0.17 \\
(3-25 / n=229)\end{array}$ & $48.51 \pm 0.42$ & $23.37 \pm 0.53$ & $28.13 \pm 0.67$ & $\begin{array}{l}264.65 \pm 46.83 \\
(n=220)\end{array}$ & $\begin{array}{l}3.36 \pm 1.42 \\
(n=220)\end{array}$ & $1 / 595$ & $1 / 500$ \\
\hline Ceiba aesculifolia & $\begin{array}{l}579.22 \pm 19.05 \\
(220-1040 / n=83)\end{array}$ & $\begin{array}{l}16.85 \pm 0.09 \\
(14-18.8 / n=83)\end{array}$ & $49.82 \pm 0.63$ & $47.18 \pm 0.90$ & $2.99 \pm 0.96$ & $\begin{array}{l}265.68 \pm 14.16 \\
(n=81)\end{array}$ & $\begin{array}{l}15.21 \pm 4.67 \\
(n=81)\end{array}$ & 0 & $2 / 25$ \\
\hline $\begin{array}{l}\text { Pseudobombax } \\
\text { ellipticum }\end{array}$ & $\begin{array}{l}214.07 \pm 24.41 \\
(20-660 / n=41)\end{array}$ & $\begin{array}{l}15.44 \pm 0.35 \\
(8-19 / n=38)\end{array}$ & $38.33 \pm 1.80$ & $26.41 \pm 1.81$ & $35.26 \pm 2.63$ & $\begin{array}{l}246.24 \pm 34.60 \\
(n=38)\end{array}$ & $\begin{array}{l}5.55 \pm 3.82 \\
(n=38)\end{array}$ & $13 / 987$ & $2 / 25$ \\
\hline Helicteres baruensis & $\begin{array}{l}35.21 \pm 9.09 \\
(10-120 / n=16)\end{array}$ & $\begin{array}{l}14.43 \pm 0.37 \\
(13-16.5 / n=12)\end{array}$ & $39.74 \pm 0.74$ & $27.80 \pm 1.44$ & $32.46 \pm 1.74$ & $\begin{array}{l}229.88 \pm 19.98 \\
(n=12)\end{array}$ & $\begin{array}{l}1.38 \pm 0.75 \\
(n=12)\end{array}$ & $3 / 100$ & $4 / 5$ \\
\hline \multicolumn{10}{|l|}{ Cactaceae } \\
\hline $\begin{array}{l}\text { Acanthocereus } \\
\text { occidentalis }\end{array}$ & $\begin{array}{l}22.05 \pm 8.33 \\
(10.8-68.7 / n=8)\end{array}$ & $\begin{array}{l}27.13 \pm 1.44 \\
(24-33 / n=6)\end{array}$ & $28.97 \pm 3.36$ & $17.06 \pm 3.14$ & $53.98 \pm 6.33$ & $\begin{array}{l}451.60 \pm 50.28 \\
(n=6)\end{array}$ & $\begin{array}{l}1.88 \pm 0.82 \\
(n=6)\end{array}$ & $13 / 100$ & $3 / 10$ \\
\hline Pachycereus pecten & $\begin{array}{l}57.06 \pm 13.09 \\
(24.4-204.2 / n=20)\end{array}$ & $\begin{array}{l}25.86 \pm 1.15 \\
(18-31 / n=11)\end{array}$ & $49.08 \pm 1.77$ & $36.80 \pm 3.14$ & $14.12 \pm 4.26$ & $\begin{array}{l}418.71 \pm 57.84 \\
(n=11)\end{array}$ & $\begin{array}{l}3.66 \pm 2.29 \\
(n=11)\end{array}$ & $4 / 475$ & $1 / 6$ \\
\hline $\begin{array}{l}\text { Stenocereus } \\
\text { chrysocarpus }\end{array}$ & $\begin{array}{l}26.47 \pm 10.80 \\
(53-114.3 / n=7)\end{array}$ & $\begin{array}{l}22.32 \pm 0.69 \\
(21-24 / n=5)\end{array}$ & $39.90 \pm 1.21$ & $41.85 \pm 4.02$ & $18.26 \pm 4.05$ & $\begin{array}{l}352.02 \pm 21.52 \\
(n=5)\end{array}$ & $\begin{array}{l}2.81 \pm 1.09 \\
(n=5)\end{array}$ & $11 / 350$ & $3 / 5$ \\
\hline Stenocereus standleyi & $\begin{array}{l}48.86 \pm 8.34 \\
(10.6-196.6 / n=25)\end{array}$ & $\begin{array}{l}24.88 \pm 0.39 \\
(22-29 / n=18)\end{array}$ & $38.42 \pm 1.02$ & $32.66 \pm 1.42$ & $28.93 \pm 1.69$ & $\begin{array}{l}395.89 \pm 27.37 \\
(n=18)\end{array}$ & $\begin{array}{l}2.50 \pm 1.70 \\
(n=18)\end{array}$ & $13 / 761$ & $1 / 10$ \\
\hline \multicolumn{10}{|l|}{ Fabaceae } \\
\hline Bauhinia pauletia & $\begin{array}{l}141.82 \pm 8.94 \\
(30-340 / n=82)\end{array}$ & $\begin{array}{l}18.12 \pm 0.14 \\
(14.8-20.5 / n=82)\end{array}$ & $36.05 \pm 0.75$ & $25.83 \pm 1.05$ & $38.11 \pm 1.16$ & $\begin{array}{l}236.43 \pm 21.13 \\
(n=81)\end{array}$ & $\begin{array}{l}4.13 \pm 2.32 \\
(n=81)\end{array}$ & $7 / 900$ & $1 / 50$ \\
\hline Bauhinia ungulata & $\begin{array}{l}165.5 \pm 24.9 \\
(n=10)\end{array}$ & & $32.00 \pm 1.57$ & $23.89 \pm 2.01$ & $44.10 \pm 1.26$ & & & $21 / 913$ & ND \\
\hline \multicolumn{10}{|l|}{ Convolvulaceae } \\
\hline Ipomoea ampullaceae & $\begin{array}{l}126.38 \pm 10.51 \\
(65-240 / n=18)\end{array}$ & $\begin{array}{l}24.42 \pm 1.03 \\
(11-30.8 / n=18)\end{array}$ & $46.58 \pm 1.68$ & $40.93 \pm 2.63$ & $12.49 \pm 2.50$ & $\begin{array}{l}421.42 \pm 68.95 \\
(n=18)\end{array}$ & $\begin{array}{l}4.82 \pm 1.94 \\
(n=18)\end{array}$ & $7 / 900$ & $4 / 5$ \\
\hline
\end{tabular}

\section{Materials and methods}

Nectar samples were collected from flowers of the 12 plant species that conform most of the annual diet of nectarivorous bats at the Chamela-Cuixmala Biosphere Reserve in the central Pacific coast of Mexico (ca. $19^{\circ} 22^{\prime}-19^{\circ} 35^{\prime} \mathrm{N}$, $104^{\circ} 56^{\prime}-105^{\circ} 03^{\prime} \mathrm{W}$; Stoner, Salazar, Fernández, \& Quesada, 2003). The predominant vegetation in the reserve is tropical dry forest, which consists mainly of tropical lowland deciduous forest with patches of riparian forest (Lott, 1993). At our study area we collected a total of 703 flowers from 12 plant species belonging to 5 families (Table 1). The number of flowers sampled per plant was variable because of differences in the flowering strategies among species, and the differences in the number of open flowers per night among individuals. The minimum number of flowers collected was 7 for Acanthocereus occidentalis and Stenocereus chrysocarpus (Cactaceae), while the maximum number of flowers collected was 240 for Ceiba pentandra (Malvaceae). For details on flowering strategies of plant species see Stoner et al. (2003).

To collect the nectar samples we covered mature flower buds using mesh bags $1 \mathrm{~h}$ before sunset. One hour after anthesis nectar was extracted, and its volume was measured with glass capillary tubes $(\mu \mathrm{l})$. Nectar was then placed on Whatman No. 1 filter paper to dry and then maintained in a dry place until sugar composition analysis was performed. Nectar concentration and sugar composition were measured for each flower collected. One drop of nectar was placed on a Leica ${ }^{\circledR}$ hand refractometer and nectar concentration was measured in sucrose equivalents $(\%$ sugar $=[$ sugar mass/total mass $] \times 100)$. Nectar samples were rehydrated with water and their sugar composition was analyzed using the Medium Infrared Reflectance Method (MIR). Samples were processed in a Spectrum 2000 FT spectrophotometer (Perkin Elmer, Boston, MA, USA; following Flores, Peñalosa, Hernández, Dávila, \& Arizmendi, 2003). Multidimensional statistical analysis was performed with Quant software (Nicolet, Madison, WI, USA) using the Partial Least Squares (PLS) algorithm to determine sugar composition. The spectra modifications employed were normalized with a baseline correction using the second derivative, and suppression of the signals of water and carbon dioxide (Flores et al., 2003). Sugar ratios were obtained (sucrose to glucose plus fructose: $\mathrm{S} / \mathrm{G}+\mathrm{F}$ ) to compare nectar sugar ratios between plant species. We recognized 4 classes of nectar: (1) sucrose-dominant nectars, when the sucrose/(glucose + fructose) ratio was greater than 0.999; (2) sucrose-rich nectar, when the ratio was between 0.5 and 0.999 ; (3) hexose-rich nectar, when the ratio was between 
0.1 and 0.499 , and (4) hexose-dominant nectar, when the ratio was less than 0.1. We used the terminology of Baker and Baker (1983) to facilitate the comparison of our results with previous studies. However, we also included the individual sugar percentages for all plant species as suggested by Nicolson and Thornburg (2007).

We calculated the energy contained in nectar by multiplying the total concentration values by each sugar values obtained by medium infrared (Flores et al., 2003); then, multiplied by their molar enthalpy value $(-2,813.1$ and $-5,647$; for hexoses and sucrose, respectively; Domalsky, 1972). Energy values where referred to $100 \mathrm{ml}$ of nectar $(\mathrm{kJ})$, and/or to mean energy per flower (in relation to the original volume found in each flower in kJ). Additionally, we obtained data of the nectar traits and flowering strategies of 37 chiropterophilic plant species (belonging to 13 families). We obtained this information from a broad review of the available literature using 'bat pollinated', 'chiropterophilic plant', 'nectar trait', 'nectar concentration', 'nectar volume' and 'nectar sugar composition' as key words in Academic Google searcher and the ISI Web of Science online databases (Appendix).

To identify interspecific relationships between nectar concentration and sugar composition, we used phylogenetically independent contrasts (PICs; Felsestein, 1985; Garland, Harvey, \& Ives, 1992). This phylogenetic comparative method allowed us to control for phylogenetic inertia (Harvey \& Pagel, 1991). We first built a preliminary phylogeny of the plant species included in our analysis using the on-line phylogenetic tool "phylomatic" (http://www.phylodiversity.net; Webb \& Donoghue, 2004), based in the angiosperms super tree, constructed with the chloroplast rbcL gene (Davis et al., 2004). We applied the maximum resolution for the seed plant phylogenetic tree. In order to obtain a fully dichotomous phylogeny, we improved the preliminary phylogeny by randomly solving polytomies (Grafen, 1992). Since some of the plant species we analyzed in this study have not been considered previously in phylogenetic studies, the branch lengths of our phylogeny were unknown. We therefore assigned a length of 1 to all branches, as suggested by Garland et al. (1992). We used the percentage of glucose, fructose and sucrose as response variables, and nectar concentration as the independent explanatory variable, including data from all 49 chiropterophilic plant species. Nectar volume was not considered in the analysis because data was available from only 8 out of 37 plant species in the literature and due to differences in sampling methodologies between the different studies (Table 1; Appendix).

To determine whether nectar concentration and sugar composition were associated with the flowering strategies of the chiropterophilic plant species, we performed a multivariate analysis of variance (Manova), where nectar traits were the response variables and flowering strategy was the explanatory factor. We characterized the flowering strategies of the 12 species analyzed in this study, either as steady state or low flower producers (lesser than 30/night per individual on average) and Big bang or high flower producers (greater than 50/night per individual; Stoner et al., 2003), and included the information we gathered from the literature for the 37 plant species previously reported in the literature (Appendix). All analyses were performed using R ( $\mathrm{R}$ Development Core Team, 2006).

\section{Results}

Nectar traits from the chiropterophilic plants at the ChamelaCuixmala Biosphere Reserve in the central Pacific coast of Mexico. Mean nectar volume values ranged from $37.3 \pm 7.54 \mu \mathrm{l}$ in A. occidentalis (Cactaceae) to $579.23 \pm 19.06 \mu 1$ in Ceiba aesculifolia (Malvaceae). The mean nectar concentration values ranged from $14.46 \pm 0.36 \%$ in Helicteres baruensis (Malvaceae) to $28 \pm 1.31 \%$ in A. occidentalis (Cactaceae). Mean fructose content values ranged from $28.97 \pm 3.14 \%$ in $A$. occidentalis (Cactaceae) to $49.82 \pm 0.63 \%$ in C. aesculifolia (Malvaceae), while mean glucose content values ranged from $17.06 \pm 2.93 \%$ in A. occidentalis (Cactaceae) to $47.18 \pm 0.90 \%$ in C. aesculifolia (Malvaceae). Fructose content was higher than glucose content in all species, except in $S$. chrysocarpus (Cactaceae). Mean sucrose content values ranged from $2.99 \pm 0.96 \%$ in C. aesculifolia (Malvaceae) to $53.98 \pm 5.92 \%$ in $A$. occidentalis (Cactaceae). Finally, mean energy values ranged from $229.88 \pm 19.98(\mathrm{~kJ})$ in H. baruensis (Malvaceae) to $451.60 \pm 50.28(\mathrm{~kJ})$ in A. occidentalis (Cactaceae) when referred to $100 \mathrm{ml}$ of nectar. However, when energy mean values where referred to energy media per flower, values ranged from $1.88 \pm 0.82(\mathrm{~kJ})$ in A. occidentalis (Cactaceae) to $15.21 \pm 4.67$ (kJ) in C. aesculifolia (Malvaceae).

After classifying all of the 49 chiropterophilic plant species in relation to their sugar content, we obtained the following distribution: 1 sucrose-dominant species, 6 sucrose-rich species, 31 hexose-rich species, and 11 hexose-dominant species. Twentyseven plant species showed greater contents of fructose than those of glucose, 21 had more glucose than fructose, and only Mucuna andreana (Fabaceae) presented equal amounts of fructose and glucose. Total nectar concentration showed a normal distribution with a mean value of $18.62 \pm 7.48 \%$ (Fig. 1). The total percentage of sucrose in nectar showed a normal leftskewed distribution, with a mean value of $16.03 \pm 10.54 \%$. Sugar concentration from hexoses showed a normal rightskewed distribution with an average value of $73.26 \pm 24.52 \%$ $(41.37 \pm 9.90 \%, 38.33 \pm 11.32 \%$ for fructose and glucose, respectively).

PCI's showed that nectar concentration was negatively related to glucose content $\left(\beta \pm \mathrm{SE}=-1.33 \pm 0.47, t_{18}=2.86, p<0.05\right)$ and positively related to the amount of fructose in solution $\left(1.19 \pm 0.25, t_{18}=4.72, p<0.01\right)$. We found no relationship between nectar concentration and sucrose content. We found that sucrose content was negatively related to both glucose and fructose contents in nectar $(-0.707 \pm 0.09, t 45=-7.073$, $p<0.01$ and $-0.21 \pm 0.11, t 45=-2.076, p<0.05$ for glucose and fructose, respectively). Finally, glucose content was negatively related to fructose content $(-0.35 \pm 0.19, t 45=-1.81$, $p<0.05$ ).

The multivariate analysis of variance revealed that nectar traits of the different chiropterophilic plant species were not related to their flowering strategy $(F 4,30=0.79, p=0.54)$. 

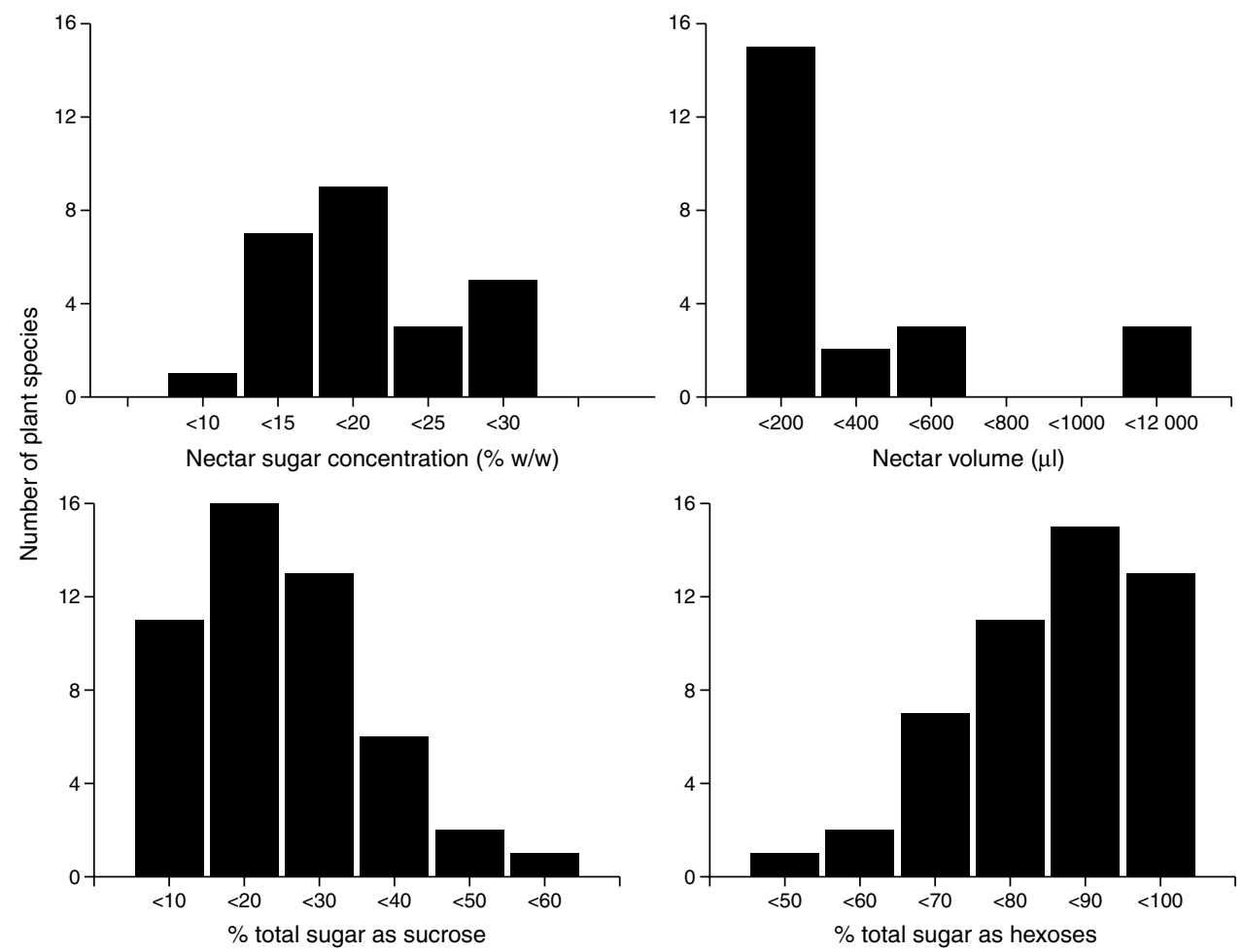

Figure 1. Nectar sugar concentration (\% w/w) and sugar composition (\% total sugar as sucrose and hexoses) mean values per species of quiropterophilic plants.

\section{Discussion}

The role of the biochemical and ecological factors that influence nectar traits in chiropterophilic plants has been poorly studied. Here, we found a general pattern in which Neotropical chiropterphilic plant species produce mainly hexose rich or hexose dominant nectars. We only found nectars with a greater amount of sucrose than hexoses in 7 out of 49 plant species. As we predicted, we found a negative relationship between nectar concentration and glucose content, and a negative relationship between sucrose and both glucose and fructose contents. Contrary to our expectations we found a positive relationship between nectar concentration and fructose content, no relationship between nectar concentration and sucrose content and a negative relationship between glucose and fructose contents. Similarly, we found no evidence that nectar traits of the different plant species were related to plant flowering strategy. In the following section we first discuss the role that biochemical factors could have on Neotropical chiropterophilic nectar sugar composition. Then, we comment on the relationship between flowering strategies and nectar traits. Finally, we discuss the relationship between the nectar characteristics of chiropterophilic plants and neotropical bats' evolution and physiology.

\section{The role of biochemical factors on nectar sugar composition}

As predicted, we found a negative relationship between sucrose and both glucose and fructose contents. This relationship can be explained considering that nectar sugars are derived from sucrose translocated from the phloem sap (De la Barrera
\& Nobel, 2004). Sucrose is either secreted into nectar, or it is hydrolyzed into hexoses by the activity of invertase enzymes (De la Barrera \& Nobel, 2004; Nicolson, 2002). As a result, the final sugar composition of nectar is determined by both the activity and amount of invertase enzyme present in the nectary walls (Sturm \& Guo-Qing, 1999; Woodson \& Wang, 1987). The hydrolysis of sucrose by the invertase enzymes renders 1 molecule of glucose and 1 molecule of fructose, per each sucrose molecule. However, we found that 48 out of the 49 species included in this study showed different proportions of glucose and fructose. Our results are similar to the sugar ratios found in some bird and insect-pollinated plants, which have different proportions of glucose and fructose (Chalcoff, Aizen, \& Galetto, 2006; Lüttge, 1962; Wenzler, Hölscher, Oerther, \& Schneider, 2008).

Three mechanisms may explain this pattern of asymmetric content of glucose and fructose in Neotropical chiropterophilic plants: (1) the biochemical effect of spontaneous mutarotation of hexoses (Ma, Schaefer, \& Allinger, 1998). The stability of cyclic forms of hexoses is differential, and glucose and fructose can take on pyranose and furanose forms, respectively. The most stable form of the minimized model in the gas phase corresponds to fructose (furanose); however, in aqueous solutions the pyranose form of glucose has greater stability (Ma et al., 1998). Notwithstanding the above, there are no studies on the differential stability of cyclic forms of hexoses in nectar; (2) the presence of additional enzymes as acidic phosphatases and transporters must be involved in generating the chemical composition of nectars (Ziegler, 1956), and (3) the action of microorganisms present in nectar. It has been reported that the biochemical action of some 
yeasts and bacterial species inhabiting the nectar could change its sugar composition (Pozo, Lievens, \& Jacquemyn, 2014), and this may occur in chiropterophilic nectars.

However, we found that glucose and fructose contents were negatively related. This result can be associated with: (1) the cycling of the different sugars taking place in nectary cells once that the enzyme invertase has hydrolyzed sucrose. After sugar uptake in the parenchyma cells, fructose could be directly phosphorylated, and half of the fructose-6-phosphate seems to be converted to glucose-6-phosphate (Wenzler et al., 2008). Then, glucose-6-phosphate could be used as sugar for nectar secretion; (2) the glucose decrease could be explained by the simple metabolic consumption of glucose in the phloem symplasm, which contains an operational glycolytic pathway (Geigenberger et al., 1993). And by the leaking and retrieval of sugars during phloem transport associated with sucrose formation in the parenchyma of the vascular bundles (Ayre, Keller, \& Turgeon, 2003; Wenzler et al., 2008), and (3) in the nectary glucose or fructose (indistinctly) can enter into the glycolysis, gluconeogenesis, and pentose phosphate pathways (Wenzler et al., 2008).

Unexpectedly, our results showed that nectar concentration was negatively related to glucose content, positively related to fructose content and not related to sucrose content. While the negative relationship between glucose content and nectar concentration was expected, and could be created by an osmotic disbalance during the hydrolysis of sucrose in the nectary (Nicolson, 1998; Nicolson \& Flemin, 2003), a positive relationship between nectar concentration and fructose content was completely unexpected. Unfortunately, no mechanisms have been proposed that could explain our results. Therefore, more work needs to be conducted on the mechanisms associated to nectar secretion in Neotropical plants.

\section{The role of flowering strategies on nectar traits}

Contrary to our hypothesis, we found no relationship between chiropterophilic plant flowering strategies and nectar sugar concentration and composition. Our results agree with those suggesting that nectar production implies small energetic costs to the plants (Golubov et al., 2004; Pyke, 1992). In this sense, historical factors of the different chiropterophilic plant species could have played a stronger influence on nectar composition than the flower production strategies adopted by the different plant species (Baker et al., 1998; Harvey \& Pagel, 1991). Although, this assessment may be true for sugar composition and nectar concentration, this hypothesis remains to be studied considering nectar volume.

\section{The relationship between the nectar characteristics of chiropterophilic plants and neotropical bats' evolution and physiology}

As we mentioned beforehand, a dichotomy involving nectar concentration and sugar composition has been observed in bird-pollinated flowers. In this dichotomy dilute and copious nectars are generally hexose-rich, while concentrated and less copious nectars are usually sucrose-rich (Nicolson, 1998, 2002). Here, we found a different pattern for chiropterophilic plant species. The differences between the nectar characteristics of ornithophilic and chiroptepophilic plants could be the result of important differences in the evolution of bird, and New-world bat pollination systems: (1) bird pollination started much earlier than New-world bat pollination. Pumiliornis tessellates is the earliest fossil of a nectar-eating bird with an age of 47 million years (Mayr \& Wilde, 2015). While Newworld bats (family Phyllostomidae) are only 39 million years old (Jones, Bininda-Emonds, \& Gittleman, 2005, Teeling et al., 2005). Dávalos (2004) has estimated that nectar-eating bats (subfamily Glossophagine) are between 12 and 17 million years old. This difference in time could have allowed for the development of a much stronger plant-pollination relationship in birds than in bats, allowing for bird pollinated plants to show clear patterns of nectar characteristics that do not exist in the case of chiropterophilic plants. Also, differences in the physiological capacities of nectar-eating birds and New-world nectarivorous bats could be responsible for molding nectar characteristics differently in these 2 pollination systems. Since bird nectar specialists can use all nectars efficiently, regardless of their sugar composition and concentration, they are not a selective force on the evolution of nectar traits. In this pollination system, non-specialized birds have acted as a selective force for dilute hexose dominated nectars in several groups of plants (Bruneau, 1997; Dupont, Hansen, Rasmussen, \& Olesen, 2004; Lotz \& Schondube, 2006). Interestingly, the New-world bat pollination system involves less than 30 species of 1 family of bats (Phyllostomidae). All are nectar specialists that have high capacities to assimilate sucrose and hexoses (Schondube, Herrera, \& Martínez-del Río, 2001), and are able to efficiently use nectars with different sugar compositions and concentrations (Ayala-Berdon \& Schondube, 2011). As a result, the lack of a dichotomy in nectar sugar concentration and composition in chiropterophilic plants could be the result of neotropical nectar-eating bats being able to use nectars with different sugar compositions. By doing so, these animals, instead of molding nectar biochemical characteristics, could have released the plants they pollinate from the selective pressures generated by other less specialized pollinators, creating the lack of pattern we found in this study.

\section{Acknowledgements}

The authors acknowledge support from grants from the Programa de Apoyo a Proyectos de Investigación e Innovación Tecnológica (PAPITT Universidad Nacional Autónoma de México) to KES (IN 226007), and to JES (IN 205413). Scholarship support to NRP was provided by the Consejo Nacional de Ciencia y Tecnología, Mexico. We thank K. A. O. Salazar for assistance in the field, L. Barbo and J. Vázquez for help in the laboratory, and the Estación de Biología Chamela for logistical support. We also would like to thank Dr. Serrano-Meneses and two anonymous reviewers for their comments in the preparation of this paper for publication. 
Appendix. Nectar traits of 37 chiropterophilic plant species reported from the literature. Volume: mean $\pm \mathrm{SD}$. Volume measurements from 24 to $48 \mathrm{~h}$ (Perret, Chautems, Spichiger, Peixoto, \& Savolainen, 2001); once in the morning in (Scogin, 1985); $2 \mathrm{~h}$ after anthesis (Petit \& Freeman, 1997); during 24 h (Wolff, 2006) and during $24 \mathrm{~h}$ in Paliavana prasinata and during $6 \mathrm{~h}$ in Sinningia brasiliensis (for P. prasinata $=22$ flowers/ 8 individuals, Sinningia brasiliensis $=12$ flowers $/ 10$ individuals) (Sanmartín-Gajardo \& Sazima, 2005). Concentration: mean $\pm \mathrm{SD}$; sugar ratios and nectar type: sucrose-dominant $(\mathrm{SD})=$ sucrose $/($ glucose + fructose $)$ ratio is greater than 0.999; sucrose-rich $(\mathrm{SR})=$ ratios between 0.5 and 0.999 ; hexose-rich $(\mathrm{HR})=$ ratios between 0.1 and 0.499 ; and hexose-dominant $(\mathrm{HD})=$ ratios less than 0.1. Sugar composition analysis by HPLC for Senecio brasiliensis, 6 flowers/3 individuals (Perret et al., 2001); sugar composition analysis by chromatography methods (Baker et al., 1998; Scogin, 1985) with no flowers $n$ reported; for Stenocereus griseus $=12$ flowers, Subpilocereus repandus $=7$ flowers (Petit \& Freeman, 1997); for Macrocarpaea arborescens $=7$ flowers $/ 4$ individuals, Macrocarpaea harlingii $=13$ flowers $/ 6$ individuals, Macrocarpaea noctiluca $=12$ flowers $/ 6$ individuals (Wolff, 2006).

\begin{tabular}{|c|c|c|c|c|c|c|c|c|}
\hline \multirow[t]{2}{*}{ Species } & \multirow{2}{*}{$\begin{array}{l}\text { Nectar } \\
\text { volume } \\
(\mu 1)\end{array}$} & \multirow{2}{*}{$\begin{array}{l}\text { Nectar } \\
\text { concentration } \\
(\mathrm{w} / \mathrm{w})\end{array}$} & \multicolumn{4}{|c|}{ Sugar composition } & \multirow{2}{*}{$\begin{array}{l}\text { Flowering } \\
\text { phenology }\end{array}$} & \multirow[t]{2}{*}{ References } \\
\hline & & & $\begin{array}{l}\text { Fructose } \\
(\%)\end{array}$ & $\begin{array}{l}\text { Glucose } \\
(\%)\end{array}$ & $\begin{array}{l}\text { Sucrose } \\
(\%)\end{array}$ & $\begin{array}{l}\text { Sugar ratio } \\
\text { (nectar type) }\end{array}$ & & \\
\hline \multicolumn{9}{|l|}{$\overline{\text { Agavaceae }}$} \\
\hline Agave havardiana & ND & ND & 36.00 & 47.00 & 17.00 & 0.20 & ND & Baker et al. (1998) \\
\hline Agave palmeri & ND & ND & 48.00 & 43.00 & 9.00 & 0.09 & ND & Baker et al. (1998) \\
\hline Agave paryi & ND & ND & 54.00 & 43.00 & 3.00 & 0.03 & ND & Baker et al. (1998) \\
\hline Agave shawii & ND & ND & 50.00 & 38.00 & 12.00 & 0.13 & ND & Baker et al. (1998) \\
\hline \multicolumn{9}{|l|}{ Asteraceae } \\
\hline Senecio brasiliensis & ND & 6.5 & 34.7 & 27.5 & 37.7 & 0.60 & ND & Perret et al. (2001) \\
\hline \multicolumn{9}{|l|}{ Bignoniaceae } \\
\hline Crescentia cujete & ND & ND & 34.00 & 40.00 & 26.00 & 0.35 & Big-bang & Baker et al. (1998) \\
\hline Kigelia pinnata & ND & 18.5 & ND & ND & ND & ND & ND & Scogin (1985) \\
\hline \multicolumn{9}{|l|}{ Cactaceae } \\
\hline Carnegiea gigantea & ND & 25 & 39.00 & 41.00 & 20.00 & 0.25 & Steady-state & $\begin{array}{l}\text { Scogin (1985) and Baker } \\
\text { et al. (1998) }\end{array}$ \\
\hline Stenocereus griseus & 500 & 12 & 20.95 & 43.27 & 11.05 & 0.17 & Steady-state & $\begin{array}{l}\text { Petit and Freeman } \\
\text { (1997) }\end{array}$ \\
\hline Stenocereus thurberi & ND & 26 & 36.00 & 47.00 & 17.00 & 0.20 & Steady-state & Baker et al. (1998) \\
\hline Subpilocereus repandus & 500 & 12 & 12.64 & 80.69 & 13.10 & 0.14 & Steady-state & $\begin{array}{l}\text { Petit and Freeman } \\
\text { (1997) }\end{array}$ \\
\hline \multicolumn{9}{|l|}{ Capparaceae } \\
\hline Crataeva tapia & ND & ND & 39.00 & 58.00 & 3.00 & 0.03 & ND & Baker et al. (1998) \\
\hline \multicolumn{9}{|l|}{ Euphorbiaceae } \\
\hline Hura crepitans & ND & ND & 53.00 & 31.00 & 16.00 & 0.19 & ND & Baker et al. (1998) \\
\hline \multicolumn{9}{|l|}{ Fabaceae } \\
\hline Bauhinia multinervia & 10,242 & 16.4 & 43.50 & 42.00 & 17.5 & 0.20 & Steady-state & Baker et al. (1998) \\
\hline Bauhinia glabra & ND & ND & 40.00 & 39.00 & 21.00 & 0.26 & Steady-state & Baker et al. (1998) \\
\hline Bauhinia ungulata & ND & ND & 35.00 & 46.00 & 19.00 & 0.23 & Steady-state & Baker et al. (1998) \\
\hline Hymenaea courbaril & ND & ND & 35.00 & 46.00 & 19.00 & 0.23 & Big-bang & Baker et al. (1998) \\
\hline Inga vera & ND & ND & 46.00 & 34.00 & 20.00 & 0.25 & Steady-state & Baker et al. (1998) \\
\hline Mucuna andreana & ND & ND & 48.00 & 48.00 & 4.00 & 0.04 & ND & Baker et al. (1998) \\
\hline Mucuna pruriens & ND & ND & 35.00 & 32.00 & 33.00 & 0.49 & ND & Baker et al. (1998) \\
\hline Mucuna rostrata & ND & ND & 48.00 & 37.00 & 15.00 & 0.17 & ND & Baker et al. (1998) \\
\hline \multicolumn{9}{|l|}{ Gentianaceae } \\
\hline Macrocarpaea arborescens & 67.90 & 23 & 43.50 & 29.60 & 26.90 & 0.36 & ND & Wolff (2006) \\
\hline Macrocarpaea harlingii & 73.1 & 11 & 36.30 & 35.30 & 28.40 & 0.39 & ND & Wolff (2006) \\
\hline Macrocarpaea noctiluca & 98.8 & 10.5 & 33.9 & 25.8 & 40.3 & 0.67 & ND & Wolff (2006) \\
\hline Paliavana prasinata & 82 & 14.3 & ND & ND & ND & ND & ND & $\begin{array}{l}\text { Sanmartín-Gajardo and } \\
\text { Sazima (2005) }\end{array}$ \\
\hline Sinningia brasiliensis & 85 & 17.5 & ND & ND & ND & ND & Steady-state & $\begin{array}{l}\text { Sanmartín-Gajardo and } \\
\text { Sazima (2005) }\end{array}$ \\
\hline \multicolumn{9}{|l|}{ Malvaceae } \\
\hline Ceiba acuminata & ND & ND & 38.00 & 29.00 & 33.00 & 0.49 & Big-bang & Baker et al. (1998) \\
\hline Ceiba speciosa & ND & ND & 53.00 & 45.00 & 2.00 & 0.02 & Big-bang & Baker et al. (1998) \\
\hline $\begin{array}{l}\text { Chiranthodendron } \\
\text { pentadactylon }\end{array}$ & ND & 12 & 50.00 & 44.00 & 6.00 & 0.06 & ND & $\begin{array}{l}\text { Scogin (1985) and Baker } \\
\text { et al. (1998) }\end{array}$ \\
\hline
\end{tabular}




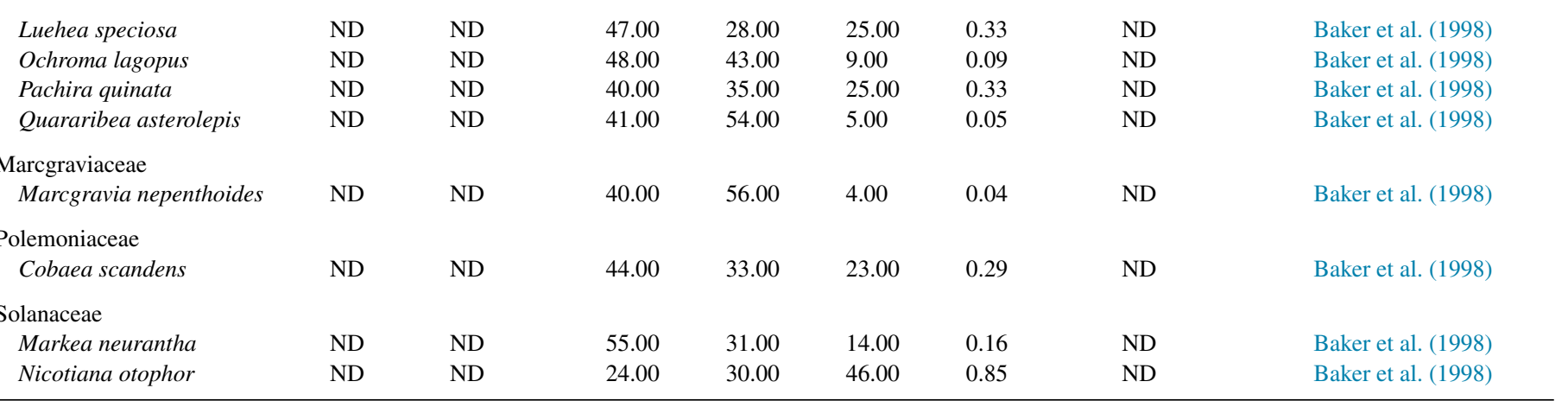

\section{References}

Ashman, T., \& Shoen, D. J. (1997). The cost of floral longevity in Clarkia rembloriensis: an experimental approach. Evolutionary Ecology, 11, 289-300.

Ayala-Berdon, J., \& Schondube, J. E. (2011). A physiological perspective on nectar-feeding adaptation in phyllostomid bats. Physiological and Biochemical Zoology, 84, 458-466.

Ayre, B. G., Keller, F., \& Turgeon, R. (2003). Symplastic continuity between companion cells and the translocation stream: long distance transport is controlled by retention and retrieval mechanisms in the phloem. Plant Physiology, 131, 1518-1528.

Baker, H. G., \& Baker, I. (1983). Floral nectars sugar constituents in relation to pollination type. In C. E. Jones, \& R. J. Little (Eds.), Handbook of experimental pollination biology (pp. 117-141). New York: Van Nostrand Reinhold.

Baker, H. G., Baker, I., \& Hodges, S. A. (1998). Sugar composition of nectars and fruits consumed by birds and bats in the tropics and subtropics. Biotropica, 30, 559-586.

Bruneau, A. (1997). Evolution and homology of bird pollination syndromes in Erythrina (Leguminosae) American. Journal of Botany, 84, 54-71.

Chalcoff, V. R., Aizen, M. A., \& Galetto, L. (2006). Nectar concentration and composition of 26 species from the temperate forest of South America. Annals of Botany, 97, 413-421.

Dávalos, L. M. (2004). Historical biogeography of the Antilles: earth history and phylogenetics of endemic chiropteran taxa (Ph.D. dissertation). New York: Columbia University.

Davis, T. J., Barranclough, T. G., Chase, M. W., Soltis, P. S., Soltis, D. E., \& Sovalainen, V. (2004). Darwin's abominable mystery: insights from a supertree of the angiosperms. Proceedings of the National Academy of Sciences of the United States of America, 101, 1904-1909.

De la Barrera, E., \& Nobel, P. S. (2004). Nectar: properties, floral aspects, and speculations on origin. Trends in Plant Science, 9, 65-69.

Domalsky, E. S. (1972). Selected values of heats of combustion and heats of formation of organic compounds containing the elements $\mathrm{C}, \mathrm{H}, \mathrm{N}, \mathrm{O}, \mathrm{P}$, and S. Journal of Physical and Chemical Reference Data, 1, 221-277.

Dupont, Y. L., Hansen, D. M., Rasmussen, J. T., \& Olesen, J. M. (2004). Evolutionary changes in nectar sugar composition associated with switches between bird and insect pollination: the Canarian bird-flower element revisited. Functional Ecology, 18, 670-676.

Erhardt, A. (1991). Nectar sugar and amino acid preferences of Battus philenor (Lepidoptera, Papilionidae). Ecological Entomology, 16, 425-434.

Faegri, K., \& van der Pijl, L. (1979). The principles of pollination ecology. Oxford: Pergamon Press.

Felsestein, J. (1985). Confidence limits on phylogenies: an approach using the bootstrap. Evolution, 39, 783-791.

Flores, C. M., Peñalosa, I., Hernández, L. B., Dávila, P. D., \& Arizmendi, M. D. (2003). Carbohydrate analysis of floral nectar using medium infrared. Phytochemical Analysis, 14, 319-324.

Garland, T., Harvey, P. H., \& Ives, A. R. (1992). Procedures for the analysis of comparative data using phylogenetically independent contrasts. Systematic Biology, 41, 18-32.

Geigenberger, P., Langenberger, S., Wilke, I., Heineke, D., Heldt, H. W., \& Stitt, M. (1993). Sucrose is metabolized by sucrose synthase and glycolysis within the phloem complex of Ricinus communis L. seedlings. Planta, 190, 446-453.

Golubov, J., Mandujano, M. C., Montaña, C., López-Portillo, J., \& Eguiarte, L. E. (2004). The demographic costs of nectar production in the desert perennial Prosopis glandulosa (Mimosidae): a modular approach. Plant Ecology, 170, 267-275.

Grafen, A. (1992). The uniqueness of the phylogenetic regression. Journal of Theoretical Biology, 156, 405-423.

Harvey, P. H., \& Pagel, M. (1991). The comparative method in evolutionary biology. Oxford: Oxford University Press.

Heinrich, B., \& Raven, P. H. (1972). Energetics and pollination ecology. Science, 176, 597-602.

Herrera, L. G. (1999). Preferences for different sugars in neotropical nectarivorous and frugivorous bats. Journal of Mammalogy, 80, 683-688.

Jones, K. E., Bininda-Emonds, O. R. P., \& Gittleman, J. L. (2005). Bats, clocks, and rocks: diversification patterns in Chiroptera. Evolution, 59, 2243-2255.

Lanza, J., Smith, G. C., Sack, S., \& Cash, A. (1995). Variation in nectar volume and composition of Impatiens capensis at individual, plant and population levels. Oecología, 102, 113-119.

Lott, E. J. (1993). Annotated checklist of the vascular flora of the Chamela Bay region Jalisco, Mexico. Occasional Papers of the California Academy of Sciences, 148, 1-60.

Lotz, C. N., \& Schondube, J. E. (2006). Sugar preferences in nectar and fruiteating birds: behavioral patterns and physiological causes. Biotropica, 38, $3-15$.

Lüttge, U. (1962). Über die zusammensetzung des nektars und den mechanismus seiner. Sekretion. II. Planta, 59, 108-114.

Ma, B., Schaefer, H. F., \& Allinger, N. L. (1998). Theoretical studies of the potential energy surfaces and compositions of the D-aldo- and D-ketohexoses. Journal of the American Chemical Society, 120, 3411-3422.

Martínez-del Río, C., Baker, H. G., \& Baker, I. (1992). Ecological and evolutionary implications of digestive processes: bird preferences and the sugar constituents of floral nectar and fruit pulp. Experientia, 48, 544-550.

Martínez-del Río, C., Schondube, J. E., \& McWhorter, T. (2001). Intake responses in nectar-feeding birds: digestive and metabolic causes, osmoregulatory consequences, and coevolutionary effects. American Zoology, 41, 902-915.

Martínez-del Río, C., Stevens, B. R., Daneke, D. E., \& Andreadis, P. T. (1988). Physiological correlates of preference and aversion for sugars in 3 species of birds. Physiological Zoology, 61, 222-229.

Mayr, G., \& Wilde, V. (2015). Eocene fossil is earliest evidence of flower-visiting by birds. Biology Letters, 10, 20140223. http://dx.doi.org/ 10.1098/rsbl.2014.0223

Nicolson, S. W. (1998). The importance of osmosis in nectar secretion and its consumption by insects. American Zoologist, 38, 418-425.

Nicolson, S. W. (2002). Pollination by passerine birds: Why are nectars so dilute? Comparative Biochemistry and Physiology, 131, 645-652.

Nicolson, S. W., \& Flemin, P. A. G. (2003). Nectar as food for birds: the physiological consequences of drinking dilute sugar solutions. Plant Systematics and Evolution, 238, 139-153.

Nicolson, S. W., \& Thornburg, R. R. (2007). Nectar chemistry. In S. Nicolson, M. Nepi, \& E. Pacini (Eds.), Nectaries and nectar (pp. 215-264). Dordrecht, The Netherlands: Springer. 
Ornelas, J. F., Ordano, M., De-Nova, A. J., Quintero, M. E., \& Garland, J. R. (2007). Phylogenetic analysis of interspecific variation in nectar of hummingbird-visited plants. Journal of Evolutionary Biology, 20, 1904-1917.

Perret, M., Chautems, A., Spichiger, R., Peixoto, M., \& Savolainen, V. (2001). Nectar sugar composition in relation to pollination syndromes in Sinningieae (Gesneriaceae). Annals of Botany, 87, 267-273.

Petit, S., \& Freeman, C. E. (1997). Nectar production of two sympatric species of columnar cacti. Biotropica, 29, 175-183.

Pleasants, J. M., \& Chaplin, S. J. (1983). Nectar production rates of Asclepias quadrifolia: causes and consequences of individual variation. Oecologia, 59, 232-238.

Pozo, M. I., Lievens, B., \& Jacquemyn, H. (2014). Impact of microorganisms on nectar chemistry, pollinator attraction and plant fitness. In Nectar: production, chemical composition and benefits to animals and plants. New York: Nova Science Publishers.

Pyke, G. H. (1992). What does it cost to a plant to produce floral nectar? Nature, 350, 58-59.

R Development Core Team. (2006). R: a language and environment for statistical computing. Vienna, Austria: Foundation for Statistical Computing. Retrieved from http://www.R-project.org

Rodríguez-Peña, N., Stoner, K. E., Schondube, J. E., Ayala-Berdon, J., FloresOrtíz, C. M., \& Martínez del Río, C. (2007). Effects of sugar composition and concentration on food selection by Saussure's Long-nosed bat (Leptonycteris yerbabuenae) and the Long-tongued bat (Glossophaga soricina). Journal of Mammalogy, 88, 1466-1474.

Sanmartín-Gajardo, I., \& Sazima, M. (2005). Chiropterophily in Sinningieae (Gesneriaceae): Sinningia brasiliensis and Paliavana prasinata are batpollinated, but P. sericiflora is not. Not yet? Annals of Botany, 95, 1097-1103.

Scogin, R. (1985). Nectar constituents of the Cactaceae. The Southwestern Naturalist, 1, 77-82.
Schondube, J. E., Herrera, L. G., \& Martínez-del Río, C. (2001). Diet and the evolution of digestion and renal function in phyllostomid bats. Zoology, 104, 59-73.

Simpson, B. B., \& Neff, J. L. (1983). Evolution and diversity of floral rewards. In C. E. Jones, \& R. J. Little (Eds.), Handbook of pollination biology. New York: Van Nostrand Reinhold.

Southwick, E. E. (1984). Photosynthate allocation to floral nectar: a neglected energy investment. Ecology, 65, 1775-1779.

Stoner, K. E., Salazar, K. A., Fernández, R. C., \& Quesada, M. (2003). Population dynamics, reproduction, and diet of the Lesser Long-nosed bat (Leptonycteris yerbabuenae) in Jalisco, Mexico: implications for conservation. Biodiversity and Conservation, 12, 357-373.

Sturm, A. Y., \& Guo-Qing, T. (1999). The sucrose-cleaving enzymes of plants are crucial for development, growth and carbon partitioning. Trends in Plant Science, 4, 401-407.

Teeling, E. C., Springer, M. S., Madsen, O., Bates, P., O’Brien, S. J., \& Murphy, W. J. (2005). A molecular phylogeny for bats illuminates biogeography and the fossil record. Science, 307, 580-584.

Webb, C. O., \& Donoghue, M. J. (2004). Phylomatic assembly for applied phylogenetics. Molecular Ecology Notes, 5, 181-183.

Wenzler, M., Hölscher, D., Oerther, T., \& Schneider, B. (2008). Nectar formation and floral nectar anatomy of Anigozanthos flavidus: a combined magnetic resonance imaging and spectroscopy study. Journal of Experimental Botany, 59, 3425-3434.

Wolff, D. (2006). Nectar sugar composition and volumes of 47 species of Gentianales from a southern Ecuadorian montane forest. Annals of Botany, 97, $767-777$.

Woodson, W. R., \& Wang, H. (1987). Invertases of carnation petals: partial purification, characterization and changes in activity during petal growth. Plant Physiology, 77, 224-228.

Ziegler, H. (1956). Untersuchungen über die Leitung und Sekretion der Assimilate. Planta, 47, 447-500. 